\title{
Effect of Modified Aspirin and Isoxsuprine Analogs on Ischemic Heart Disease
}

\author{
Laraib Ghazi ${ }^{1{ }^{1 *}, \text { Muddassir Shabbir Khanzada }}{ }^{2}$, Anum Munir ${ }^{1}, \operatorname{Sajid~Khan}^{1}$, Muhammad Rizwan ${ }^{1}$, \\ Azhar Mehmood ${ }^{1}$ \\ ${ }^{1}$ Department of Bioinformatics, Government Post Graduate College Mandian, Abbottabad, Pakistan \\ ${ }^{2}$ Abbottabad International Medical Institute, Abbottabad, Pakistan
}

Received March 11, 2020; Revised May 19, 2020; Accepted May 23, 2020

Copyright $(2020$ by authors, all rights reserved. Authors agree that this article remains permanently open access under the terms of the Creative Commons Attribution License 4.0 International License

\begin{abstract}
Ischemic heart disease (IHD) or coronary artery disease $(\mathrm{CAD})$ is one of the largest death-causing reasons in developing countries. Approximately, every year 15 million deaths due to IHD are reported worldwide. PLG (Plasminogen), PCSK9 (Proprotein Convertase Subtilisin/Kexin type 9), CXCL12 (C-X-C Motif Chemokine Ligand 12), and EDNRA (Endothelin Receptor type A) genes were selected for the study due to their higher rate of mutations in IHD. Drugs that are being used to cure IHD were reformulated by structurally modifying them for repurposing. Reformulated drugs were further analyzed for side effects, toxicity, and ADMET (Absorption, Distribution, Metabolism, Excreation, Toxicity) properties. Molecular docking studies of reformulated drugs with selected genes were performed to determine their efficacy to cure IHD. Interacting amino acid residues in the docked complex of aspirin were identified as Aspartic acid, Arginine, Tyrosine, Proline, Valine, Alanine, Threonine, Iso Leusine, Lysine, Triptophan, Aspargine, Histadine and Cystine. Similarly, for isoxsuprine the residues were Valine, Aspargine, Leucine, Argining, Iso Leucine, Glutamic acid, Lysine, Glycine, Proline, Threonine, Aspartic acid, Histadine, Arginine. In reformulated compounds, the addition of sulfur in the aspirin compound reduced the toxicity from class 3 to class 5 and in isoxsuprine, the addition of nitrogen hydrogen bond in the second aromatic ring reduced its toxicity from class 3 to class 4 . It is suggested that both aspirin and isoxsuprine analogs are more effective having least predicted side effects and toxicities than already existing aspirin and isoxsuprine. In the future, these drugs can be used as potential drugs for the treatment of IHD than original drugs because of their low toxicity and side effects. This study can be validated in vitro to confirm its efficacy.
\end{abstract}

Keywords Aspirin, Isoxsuprine, IHD, CAD, Reformulation

\section{Introduction}

Ischemic Heart Disease (IHD) resulting from blockage or narrowing of a coronary artery and is associated with an insufficient supply of oxygen-rich blood to the myocardium. It is a multifactorial atherosclerotic pathology [1]. IHD can be defined as more than $50 \%$ narrowing in diameter of the left coronary artery or $>70 \%$ luminal narrowing of $2 \mathrm{~mm}$ diameter of three major epicardial arteries. Left main coronary artery (LMCA) disease is one of the major risk factors of morbidity and mortality [2]. Deaths due to IHD can be divided into 2 categories: sudden cardiac deaths and acute myocardial infarction deaths [3]. The common cause of heart failure is myocardial infarction (MI) that is caused by prolonged duration ischemia. Ischemia can vary from short to long duration and from low flow to total coronary occlusion [4]. According to the World Health Organization, every year in the world 15 million deaths are caused by cardiovascular diseases. These deaths are mostly premature and under the age of 65 [5]. The mortality rate from IHD in Pakistan is 410/100000 [6]. Despite advancements in diagnostic and therapeutic approaches, it is still the leading cause of death in developing countries [7].

Women are at greater risk of having IHD as compared with men [8].This is consistent with the findings of Jafar[9] in which case, after surveying 3143 adults (equal or greater than 40 years), they found that ischemic and ECG changes were twice in women as compared with men. According to annual population statistical data, the death rate of women vs man is $(455,000$ vs. 410,000$)$ [10].

McNeil [11] conducted a randomized, double-blind, placebo-controlled clinical trial to investigate the effect of daily use of $100 \mathrm{mg}$ of enteric-coated aspirin in community-dwelling older adults. They found that the risk 
of major hemorrhage was significantly higher with aspirin than placebo, suggesting that the risk of bleeding persisted over the course of aspirin therapy. In a similar study by Bowman [12] a randomized clinical trial was conducted for persons with diabetes. They found that a lower risk of serious vascular events was resulted in the use of low-dose aspirin group than in placebo group. However, the absolute lower risk of such vascular events was counterbalanced by the higher bleeding rates, even among persons with high vascular risk.

Joseph [13] conducted a low-dose aspirin (along with placebo) therapy on patients with peptic ulcer bleeding. The continuous low-dose aspirin therapy potentially reduced overall mortality but increased the risk for recurrent bleeding. Edward[14] conducted a study over 24 years of follow-up and they found that the risk of gastrointestinal bleeding was more intensely associated with the aspirin dose than the duration of aspirin use.

Isoxsuprine also known as a vasodilator is a beta-adrenergic that helps in peripheral vascular dilation by relaxing muscles, arteries, and veins by making them wider to allow the passing of blood more easily [15]. Isoxsuprine is used to produce short-term salutary effects in ischaemic vascular disease and heart failure. Edilberto [16] conducted a clinical experiment on 12 patients (11 men and 1 woman) with congestive heart failure (CHF). They investigated the cardiovascular effects of isoxsuprine in those patients. During the short term efficacy of isoxsuprine, all the patients showed improved signs and symptoms of CHF.

In the last two years the rate of approval of drugs by Food and Drug Administration (FDA) has increased twofold approximately from historical rate of approval of 26.8 per year to 46 and 59 drugs in 2017 and 2018 respectively but still overall rate of new drugs coming to the market is low [17]. New drug designing, its development, and registration often require 10-17 years with a cost of around USD $\$ 1.5$ billion, and $70-90 \%$ of drugs fail in clinical trials [18]. Drug repurposing, is a new next generation approach that increases the drug discovery speed at low cost [17]. Repurposing the existing (already approved) drugs for mitigating the IHD is beneficial for being more affordable and less time-consuming than novel drug discovery. In fact, such a technique can prove to be cost-effective than producing new drugs. For instance, the cost of drug development reduces to $50 \%$ by using ADR prediction technologies [19].

According to Schooling[20], approximately 173 genes were associated with CAD but of them, only 8 genes were associated with the treatment of IHD i.e., PLG (Plasminogen), PCSK9 (Proprotein Convertase Subtilisin/Kexin type 9), CXCL12 (C-X-C Motif Chemokine Ligand 12), EDNRA (Endothelin Receptor type A), LRP1 (LDL Receptor Related Protein 1), LPL (Lipoprotein Lipase), ADORA2A (Adenosine A2a Receptor), and CETP (Cholesteryl Ester Transfer Protein). From 173 genes associated with IHD, only 8 genes were the products of the 236 autosomal genes that were involved in the treatments of IHD [20]. To the best of our knowledge, very little to almost no research has been conducted on the repurposing of aspirin and isoxsuprine, which was the motivation behind the current research work.

This study aims to repurpose two of the most prescribed drugs in the cardiovascular field, namely, aspirin and isoxsuprine to reduce their toxicity. Our primary research question was based on the prediction of the toxicity levels and the side effects of the modified aspirin and isoxsuprine in comparison with the original drugs.

\section{Material and Methods}

This section deals with the data collection and processing of selected genes based on already published literature that will be discussed in the subsequent sub-sections. The overall methodology steps that were followed during the current research work are shown in Figure 1; on a more specific level, these steps will be discussed under the following headings.

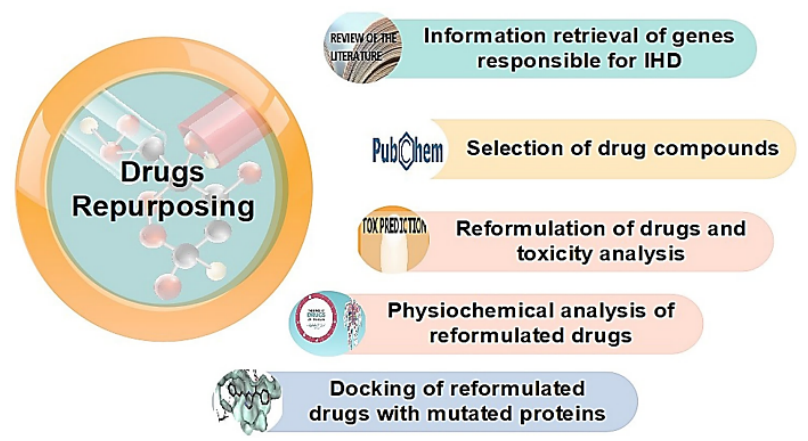

Figure 1. Graphical representation of the complete methodology of the research work

\subsection{Information Retrieval of Genes Responsible for IHD}

Information about the LRP1, PCSK9, PLG, CETP, ADORA2A, LPL CXCL12, and EDNRA genes associated with IHD was obtained through literature review [20]. By using Research Collaboratory for Structural Bioinformatics (RCSB), protein database (PDB) mutated protein ids of CETP, LPL, EDNRA, CXCL12, PLG, LRP1, ADORA2A and PCSK9 were obtained. RCSB PDB database provides three-dimensional Nuclear Magnetic Resonance (NMR) nucleic acid and protein structures and their X-ray crystallographic structures. From the above genes associated with IHD, only 4 genes PCSK9, EDNRA, PLG, and CXCL12 were highly mutated and the rest of the 4 genes were wild; so, they were not included in the study. EDNRA encodes a highly mutated protein 5XPR that has 9 mutations, PCSK9 encodes protein 4K8R that has 2 mutations, PLG encodes 2DOI having 1 mutation, and CXCL12 encodes 3 OE8 that has 3 mutations. Figure 2 
shows the 3D structure of these mutated proteins obtained from PDB.

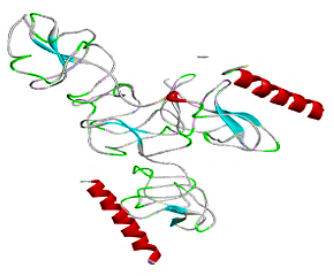

a) $2 \mathrm{DOI}$

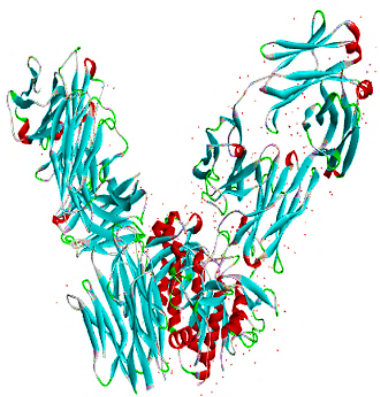

c) $4 \mathrm{~K} 8 \mathrm{R}$

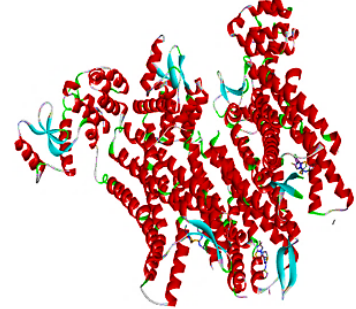

b) $30 \mathrm{OE}$

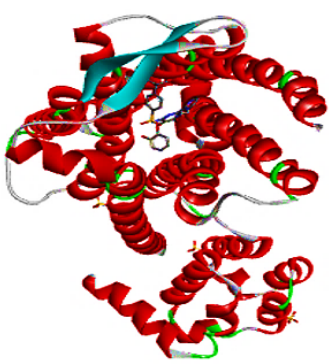

d) 5XPR
Figure 2. $3 \mathrm{D}$ structure of mutated proteins of ischemic heart disease. a) 2DOI b) $3 \mathrm{OE} 8$ c) $4 \mathrm{~K} 8 \mathrm{R}$ d) $5 \mathrm{XPR}$.

\subsection{Selection of Drug Compounds}

To obtain organic test results and compound structures, PubChem contains data about chemical substances and their biological activities [21]. By using the PubChem database, chemical structures of aspirin with chemical name 2-Acetoxybenzoic acid and isoxsuprine with chemical

name

4-[1-hydroxy-2-(1-phenoxypropan-2-ylamino)propyl]phe nol were downloaded. Figure 3 represents the chemical structures of aspirin and isoxsuprine obtained from PubChem.

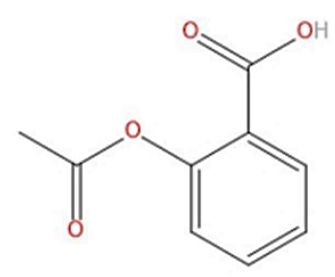

Aspirin

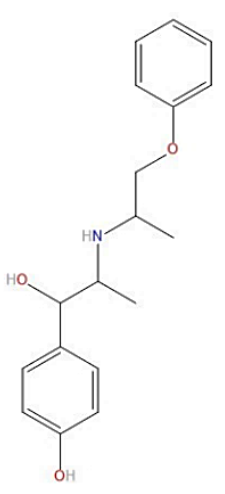

Isoxsuprine
Figure 3. Aspirin and Isoxsuprine chemical structures downloaded from the Pubchem database

\subsection{Reformulation of Drugs and Toxicity Analysis}

Aspirin and isoxsuprine were modified to reduce their toxicity. Quantitative structure-activity relationships (QSAR) were also analyzed. For toxicity endpoints prediction such as acute toxicity, cytotoxicity, mutagenicity, hepatotoxicity, carcinogenicity, immunotoxicity, toxicity targets, and adverse outcomes pathways, ProToxII server was used [22]. New compounds were designed in discovery studio software and again checked from the ProTox-II server that showed their low toxicity class and fewer side effects as compared with the original drug.

Physiochemical analysis was performed by calculating ADMET properties of the drug. These properties were calculated by using admetSAR.

\subsection{Docking of Repurposed Drugs with Mutated Genes to Determine Their Interactions}

Through the PatchDock server, the drugs were docked with the 3D structure of mutated proteins.

\section{Results and Discussions}

Before reformulating aspirin and isoxsuprine, they were present in high toxicity classes in lethal doses (LD50). The acute toxicity of a drug is calculated by LD50 i.e., of a particular species, $50 \%$ of animals will be killed with the dose [23]. Figure 4 represents modified aspirin and isoxsuprine.
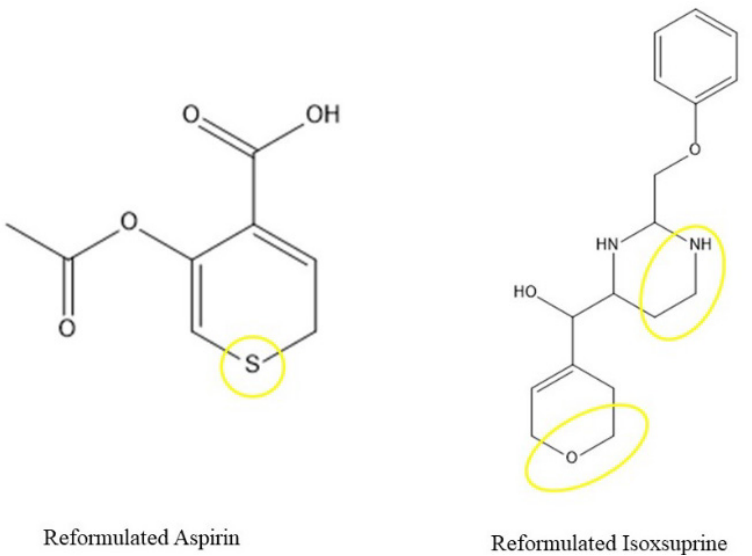

Figure 4. Modified structures of aspirin and Isoxsuprine.

Table 1. Toxicity classes of reformulated drugs and their adverse effects on the body.

\begin{tabular}{|c|c|c|}
\hline Properties & $\begin{array}{c}\text { Reformulated } \\
\text { ASPIRIN }\end{array}$ & $\begin{array}{c}\text { Reformulated } \\
\text { ISOXSUPRINE }\end{array}$ \\
\hline Toxicity class & 5 & 4 \\
\hline LD50 & $5000 \mathrm{mg} / \mathrm{kg}$ & $2000 \mathrm{mg} / \mathrm{kg}$ \\
\hline Molecular weight & 200.21 & 304.38 \\
\hline Organ toxicity \\
\hline Hepatotoxicity & Inactive & Inactive \\
\hline Carcinogenicity & Inactive & Inactive \\
\hline Immunotoxicity & Inactive & Inactive \\
\hline Mutagenicity & Inactive & Inactive \\
\hline Cytotoxicity & Inactive & Inactive \\
\hline
\end{tabular}


Table 1 represents the adverse effects of the modified drugs on the human body calculated from ProtoxII.

After reformulation, the toxicity class of aspirin was reduced from class 3 to class 5. Similarly toxicity class of isoxsuprine was reduced from class 3 to class 4 .

Table 2 describes the ADMET properties of drugs in the body.

Table 2. Drug ADMET effects on the body.

\begin{tabular}{|c|c|c|c|c|c|c|c|}
\hline \multicolumn{4}{|c|}{ Absorption } & \multicolumn{4}{|c|}{ Metabolism } \\
\hline Properties & Aspirin & ISOXSUPRIN & Unit & Properties & Aspirin & ISOXSUPRIN & Unit \\
\hline & \multicolumn{2}{|c|}{ values } & & & \multicolumn{2}{|c|}{ values } & \\
\hline Water solubility & -0.607 & -1.856 & $\begin{array}{c}\text { Numeric } \\
(\log \mathrm{mol} / \mathrm{L})\end{array}$ & $\begin{array}{l}\text { CYP2D6 } \\
\text { substrate }\end{array}$ & No & No & $\begin{array}{c}\text { Categorical } \\
\text { (Yes/No) }\end{array}$ \\
\hline $\begin{array}{c}\text { Caco2 } \\
\text { permeability }\end{array}$ & 0.592 & 0.511 & $\begin{array}{c}\text { Numeric } \\
(\log \text { Papp in } \\
10 \mathrm{~cm} / \mathrm{s})\end{array}$ & $\begin{array}{l}\text { CYP3A4 } \\
\text { substrate }\end{array}$ & No & Yes & $\begin{array}{c}\text { Categorical } \\
\text { (Yes/No) }\end{array}$ \\
\hline $\begin{array}{c}\text { Intestinal } \\
\text { absorption } \\
\text { (human) }\end{array}$ & 90.682 & 74.474 & $\begin{array}{l}\text { Numeric(\% } \\
\text { Absorbed) }\end{array}$ & $\begin{array}{l}\text { CYP1A2 } \\
\text { inhibitor }\end{array}$ & No & No & $\begin{array}{l}\text { Categorical } \\
(\text { Yes/No) }\end{array}$ \\
\hline $\begin{array}{c}\text { Skin } \\
\text { Permeability }\end{array}$ & -2.747 & -3.088 & $\begin{array}{l}\text { Numeric } \\
(\log K p)\end{array}$ & $\begin{array}{c}\text { CYP2C19 } \\
\text { inhibitor }\end{array}$ & No & No & $\begin{array}{c}\text { Categorical } \\
\text { (Yes/No) }\end{array}$ \\
\hline $\begin{array}{c}\text { Pglycoprotein } \\
\text { Substrate }\end{array}$ & No & Yes & $\begin{array}{l}\text { Categorical } \\
\text { (Yes/No) }\end{array}$ & $\begin{array}{l}\text { CYP2C9 } \\
\text { inhibitor }\end{array}$ & No & No & $\begin{array}{c}\text { Categorical } \\
\text { (Yes/No) }\end{array}$ \\
\hline $\begin{array}{l}\text { Pglycoprotein } \\
\text { I inhibitor }\end{array}$ & No & No & $\begin{array}{c}\text { Categorical } \\
\text { (Yes/No) }\end{array}$ & $\begin{array}{l}\text { CYP2D6 } \\
\text { inhibitor }\end{array}$ & No & No & $\begin{array}{c}\text { Categorical } \\
\text { (Yes/No) }\end{array}$ \\
\hline $\begin{array}{l}\text { Pglycoprotein } \\
\text { II inhibitor }\end{array}$ & No & No & $\begin{array}{c}\text { Categorical } \\
\text { (Yes/No) }\end{array}$ & $\begin{array}{l}\text { CYP3A4 } \\
\text { inhibitor }\end{array}$ & No & No & $\begin{array}{c}\text { Categorical } \\
\text { (Yes/No) }\end{array}$ \\
\hline \multicolumn{4}{|c|}{ Distribution } & \multicolumn{4}{|c|}{ Toxicity } \\
\hline \multirow[t]{2}{*}{ Properties } & Aspirin & ISOXSUPRIN & Unit & Properties & Aspirin & ISOXSUPRIN & Unit \\
\hline & \multicolumn{2}{|c|}{ Value } & & & \multicolumn{2}{|c|}{ Value } & \\
\hline VDss (human) & 0.4 & 0.898 & $\begin{array}{c}\text { Numeric } \\
(\log L / k g)\end{array}$ & AMES toxicity & No & No & $\begin{array}{c}\text { Categorical } \\
\text { (Yes/No) }\end{array}$ \\
\hline $\begin{array}{l}\text { Fraction } \\
\text { unbound } \\
\text { (human) }\end{array}$ & 0.577 & 0.798 & Numeric $(\mathrm{Fu})$ & $\begin{array}{l}\text { Max. tolerated } \\
\text { dose (human) }\end{array}$ & 0.973 & -0.647 & $\begin{array}{c}\text { Numeric (log } \\
\mathrm{mg} / \mathrm{kg} / \text { day) }\end{array}$ \\
\hline $\begin{array}{c}\text { BBB } \\
\text { permeability }\end{array}$ & 0.682 & -0.054 & $\begin{array}{l}\text { Numeric } \\
(\log B B)\end{array}$ & $\begin{array}{l}\text { hERG I } \\
\text { inhibitor }\end{array}$ & No & No & $\begin{array}{c}\text { Categorical } \\
\text { (Yes/No) }\end{array}$ \\
\hline $\begin{array}{c}\text { CNS } \\
\text { permeability }\end{array}$ & -4.209 & -2.857 & $\begin{array}{l}\text { Numeric } \\
(\log P S)\end{array}$ & $\begin{array}{l}\text { hERG II } \\
\text { inhibitor }\end{array}$ & No & Yes & $\begin{array}{l}\text { Categorical } \\
\text { (Yes/No) }\end{array}$ \\
\hline \multicolumn{4}{|c|}{ Excretion } & $\begin{array}{l}\text { Oral Rat Acute } \\
\text { Toxicity (LD50) }\end{array}$ & 1.978 & 2.905 & $\begin{array}{l}\text { Numeric } \\
(\mathrm{mol} / \mathrm{kg})\end{array}$ \\
\hline \multirow[t]{2}{*}{ Properties } & Aspirin & ISOXSUPRIN & Unit & $\begin{array}{c}\text { Oral Rat } \\
\text { Chronic } \\
\text { Toxicity } \\
\text { (LOAEL) } \\
\end{array}$ & 0.771 & 1.108 & $\begin{array}{c}\text { Numeric (log } \\
\mathrm{mg} / \mathrm{kg} \text { bw/day) }\end{array}$ \\
\hline & \multicolumn{2}{|c|}{ Values } & & Hepatotoxicity & No & Yes & $\begin{array}{c}\text { Categorical } \\
(\text { Yes } / \mathrm{No})\end{array}$ \\
\hline Total Clearance & 0.336 & 1.05 & $\begin{array}{c}\text { Numeric (log } \\
\mathrm{ml} / \mathrm{min} / \mathrm{kg})\end{array}$ & $\begin{array}{c}\text { Skin } \\
\text { Sensitisation }\end{array}$ & No & No & $\begin{array}{c}\text { Categorical } \\
\text { (Yes/No) }\end{array}$ \\
\hline $\begin{array}{c}\text { Renal OCT2 } \\
\text { substrate }\end{array}$ & No & No & $\begin{array}{l}\text { Categorical } \\
\text { (Yes/No) }\end{array}$ & $\begin{array}{l}\text { T.Pyriformis } \\
\text { toxicity }\end{array}$ & 0.08 & 0.242 & $\begin{array}{c}\text { Numeric (log } \\
\text { ug/L) }\end{array}$ \\
\hline
\end{tabular}




\subsection{Docking of Reformulated Drugs with Mutated Proteins}

For find out the best compounds, molecular docking and virtual screening are the best sources [19]. 3OE8, 2DOI, 5XPR, 4K8R mutated proteins docked with the modified aspirin and isoxsuprine. For docking purposes, Patchdock sever was used by defining its parameter 2.0. Figures 5 and 6 show the docking of reformulated drugs with mutated proteins. In each of these figures, ligand fits in the binding pocket of mutated receptor protein and demonstrating strong interactions towards the binding pocket with minimum distance between them that confirmed the efficacy of binding [24, 25].
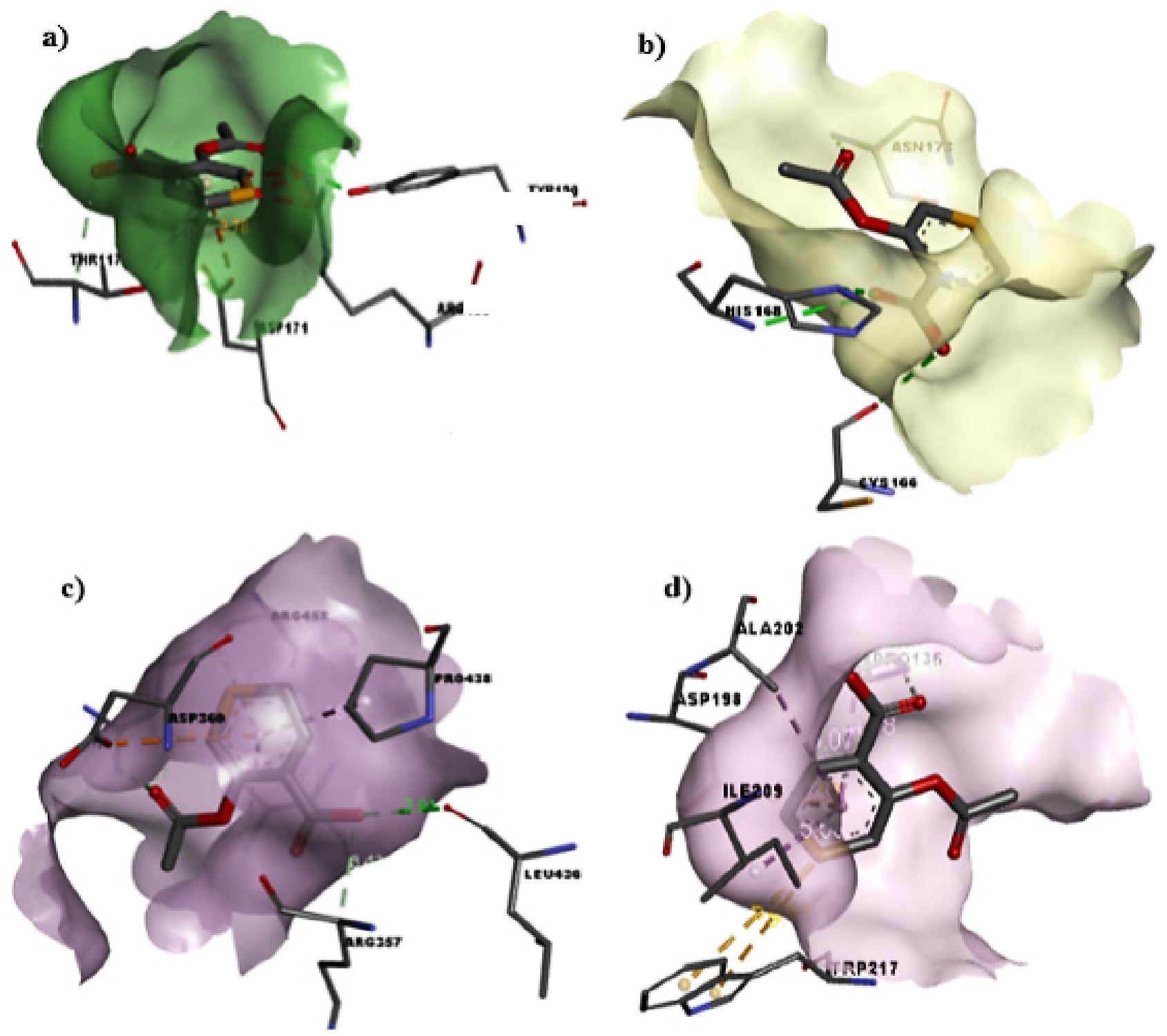

Figure 5. Docked complexes of modified aspirin with mutated proteins: a) Reformulated aspirin docked with $3 \mathrm{OE} 8$ b) Aspirin docked with $2 \mathrm{DOI} \mathbf{c})$ Docked aspirin with 4K8R d) Modified aspirin docked with 5XPR. 

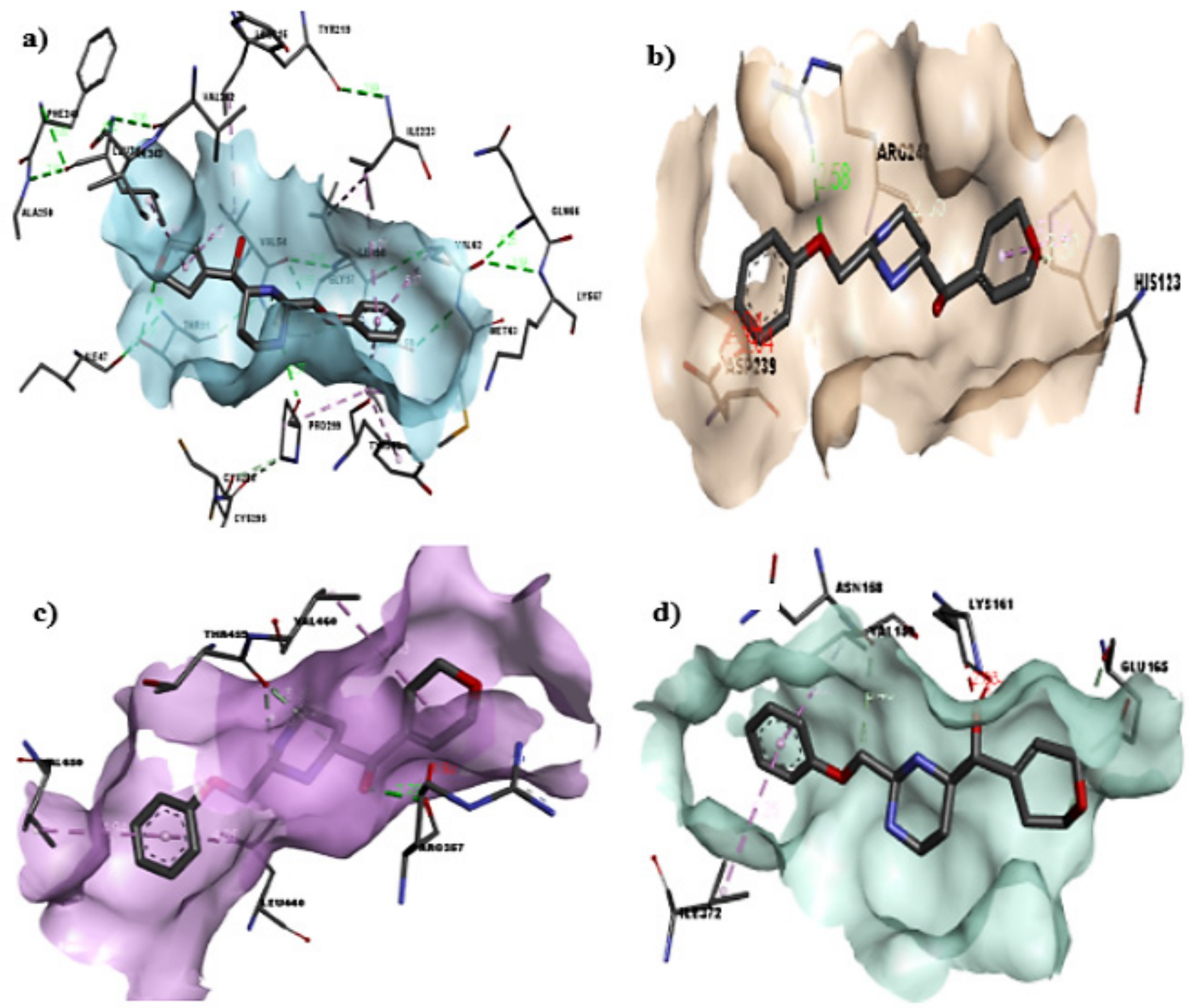

Figure 6. Docked complexes of modified isoxsuprine with mutated proteins: a) Modified isoxsuprine docked with $3 \mathrm{OE} 8$ b) Isoxsuprine docked with 2DOI c) Isoxsuprine docked with 4K8R d) Isoxsuprine docked with 5XPR. 


\subsection{D Interactions of Aspirin with Mutated Proteins}

2D interactions showed the interacting amino acid residues of the binding pocket of the mutated protein and modified drugs. Minimum unfavorable bumps were found between them. These results validated docking and modified drugs as the best drugs based on the reduced levels of toxicity and side effects. Figures 7 and 8 represent $2 \mathrm{D}$ interactions of aspirin and isoxsuprine respectively, whereby different interaction colors represent different types of bonding interactions present between them. Types of interactions are described by legends and are shown in Figures 7 and 8 .
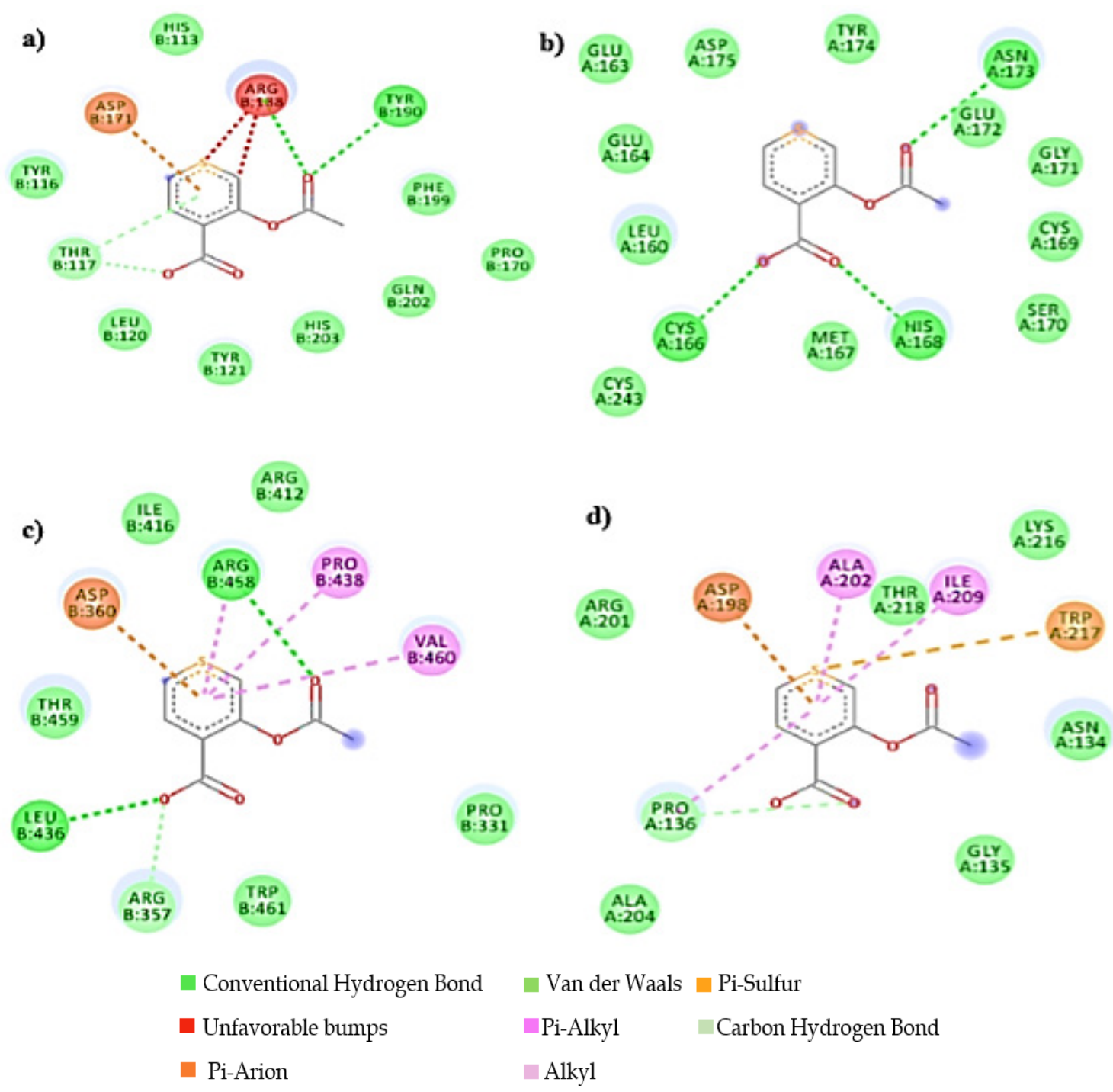

Figure 7. 2D interactions of modified aspirin with amino acid residueswithin the binding pocket of mutated proteins. a) Interacting amino acid residues of $3 \mathrm{OE} 8$ and modified aspirin b) Aspirin interactions with 2DOI c) Amino acid interactions of the binding pocket of 4K8R with aspirin d) Interacting residues of aspirin and $5 \mathrm{XPR}$. 


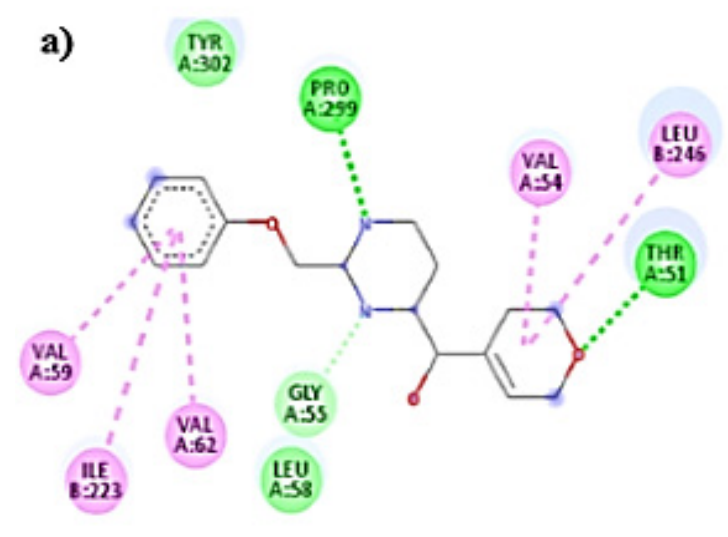

c)

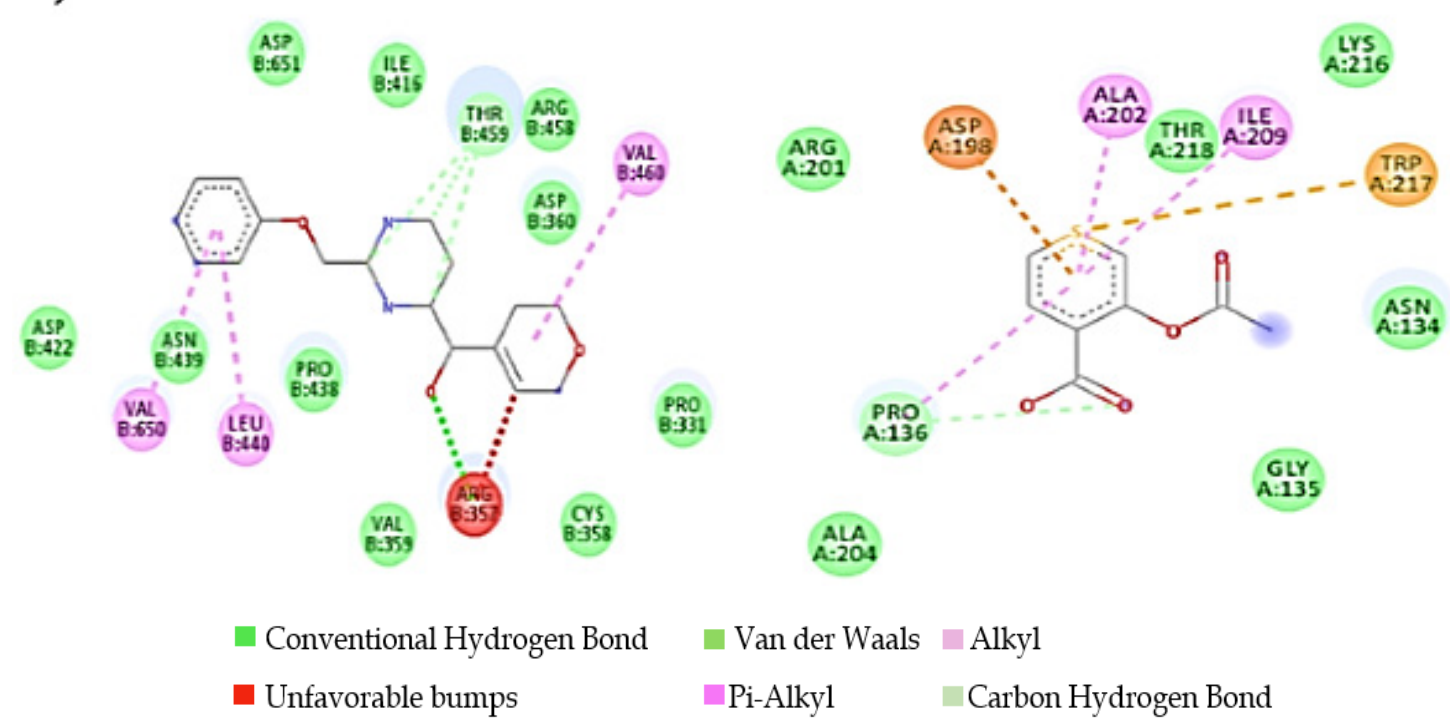

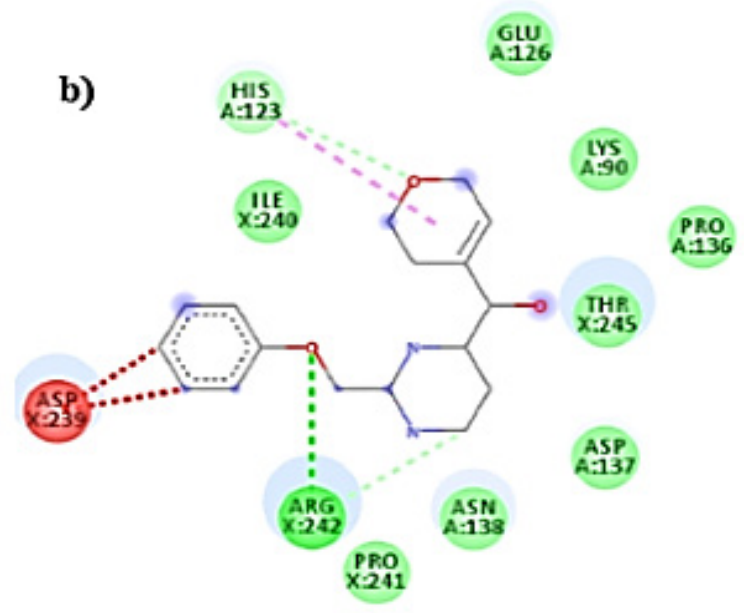

d)

Figure 8. 2D interactions of amino acid residues of the binding pocket of mutated proteins with modified isoxsuprine. a) Interaction of isoxsuprine with $3 \mathrm{OE} 8 \mathrm{~b}$ ) Interactions of isoxsuprine with 2DOI c) Reformulated isoxsuprine interactions with residues of 4K8R d) Isoxsuprine interactions with binding pocket residues of 5XPR.

Low toxicity values, fewer side effects, docking results, and strong interactions of both modified aspirin and isoxsuprine suggest that both these modified drugs can be used to cure mutated genes of IHD. As compared with the original drugs, both modified drugs showed the strongest interactions with the amino acid residues of binding pockets that determine drugs soundness and stability. Greater interactions reflected the best drug candidates.

Here the approach is used to reformulate these two drugs to reduce their toxicity and side effects probability on several body organs. Reformulation refers to design different formulations for the same pharmaceutical drug [21]. Reformulated drugs were docked with the mutated proteins of ischemic heart disease to prove their stability as drug candidates. Docking results showed the best interaction between active binding pocket amino acid residues of mutated protein and drug candidates that prove their best stability with the mutated proteins. ADMET properties of drugs were also calculated to check the side effect ratio of repurposed drugs on the body that was very low as compared with the original drugs. These drugs were found to having low toxicity classes. So these modified drugs can be suggested as the best drugs for the treatment of ischemic heart disease as their developmental cost and time is also less than introducing a new drug.

\section{Conclusions}

Reformulated aspirin and isoxsuprine are more effective and the probability of their side effects is identified to be less than the original compounds. Addition of Sulphur in aspirin compound reduces its toxicity from class 3 to class 5 and in isoxsuprine, the addition of nitrogen hydrogen 
bond in the second aromatic ring reduces its toxicity from class 3 to class 4 . While performing docking with the binding pocket atoms and amino acid residues of mutated proteins, the repurposed drugs show greater interactions that define their stability. In QSAR analysis, drugs have shown fewer side effects on the body parts as compared with the original drugs. These results suggested that reformulated drugs can be suggested as the best drugs used for the CAD treatment as compared with the original drugs. In the future, this research work can be used for a clinical trial to check their efficacy and social importance.

\section{Acknowledgements}

We gratefully acknowledge the valuable suggestions by Noor Yaseen.

\section{REFERENCES}

[1] Adam, A. M. Prevalence of Conventional Risk Factors and Evaluation of Baseline Indices Among Young and Elderly Patients with Coronary Artery Disease. Journal of clinical and diagnostic research. (2017).

[2] Awan, A., \& Malik, M. N. Frequency of Left Main Coronary Artery Disease in Patient Presenting for Coronary Angiography to Cardiac Cath. Lab, Hayatabad Medical Complex Peshawar. Ann. Pak. Inst. Med. Sci, 79. (2017).

[3] Moran, A. E., Forouzanfar, M. H., Roth, G. A., Mensah, G. A., Ezzati, M., Murray, C. J., \& Naghavi, M. Temporal trends in ischemic heart disease mortality in 21 world regions, 1980 to 2010: the Global Burden of Disease 2010 study. Circulation, 129(14), 1483-1492. (2014).

[4] Lindsey, M. L., Bolli, R., Canty, J. M., Du, X.-J., Frangogiannis, N. G., Frantz, S., Heusch, G. Guidelines for experimental models of myocardial ischemia and infarction. American Journal of Physiology-Heart and Circulatory Physiology, 314(4), H812-H838. (2018).

[5] Iqbal, S. P., Dodani, S., \& Qureshi, R. Risk factors and behaviours for coronary artery disease (CAD) among ambulatory Pakistanis. Journal-Pakistan medical associateion. 54(5), 261-265. (2004).

[6] Samad A, Sahibzada WA, Mattu A, et al. Risk factor analysis in a random population of 4 cities in Pakistan. Pakistan J Cardiol 1992;3:7-14. (2014)

[7] Global Health Estimates 2016: Deaths by cause, age, sex, by country and by region, 2000-2016. Geneva, Switzerland: World Health Organization; 2018. http://www.who.int/healthinfo/global_burden_disease/esti mates/en/. Accessed November 16, 2018.

[8] Shaw, L. J., Bugiardini, R., \& Merz, C. N. B. Women and ischemic heart disease. Journal of the American college of cardiology, 54(17), 1561-1575. (2009).

[9] Jafar, T. H., Qadri, Z., \& Chaturvedi, N. Coronary artery disease epidemic in Pakistan: more electrocardiographic evidence of ischaemia in women than in men. Heart, 94(4), 408-413. (2007).

[10] Centers for Disease Control and Prevention. State-Specific Mortality from Sudden Cardiac Death United States, 1999. http://www.cdc.gov/mmwr/preview/mmwrhtml/mm5106a 3.htm. Accessed (2008).

[11] McNeil, J. J., Wolfe, R., Woods, R. L., Tonkin, A. M., Donnan, G. A., Nelson, M. R., Reid, C. M., Lockery, J. E., Kirpach, B., Storey, E., Shah, R. C., Williamson, J. D., Margolis, K. L., Ernst, M. E., Abhayaratna, W. P., Stocks, N., Fitzgerald, S. M., Orchard, S. G., Trevaks, R. E., ... Murray, A. M. Effect of Aspirin on cardiovascular events and bleeding in the healthy elderly. New England journal of medicine, 379(16), 1509-1518. https://doi.org/10.1056/NEJ Moa1805819. (2018).

[12] The ascend study collaborative group. Effects of Aspirin for primary prevention in Persons with diabetes mellitus. New England journal of medicine, 379(16), 1529-1539. https://doi.org/10.1056/NEJMoa1804988. (2018).

[13] Sung, J. J., Lau, J. Y., Ching, J. Y., Wu, J. C., Lee, Y. T., Chiu, P. W., \& Chan, F. K. Continuation of low-dose aspirin therapy in peptic ulcer bleeding: a randomized trial. Annals of internal medicine, 152(1), 1-9. (2010).

[14] Huang, E. S., Strate, L. L., Ho, W. W., Lee, S. S., \& Chan, A. T. Long-term use of Aspirin and the risk of gastrointestinal bleeding. The American journal of medicine, 124(5), 426433. https://doi.org/10.1016/j.amjmed.2010.12.022. (2011).

[15] Alavi, A., Rajaee, M., Amirian, M., Mahboobi, H., Jahanshahi, K. A., \& Faghihi, A. Effect of maintenance therapy with isoxsuprine in the prevention of preterm labor: randomized controlled trial. Electronic physician,7(4), 1144. (2015).

[16] Gozo Jr, E. G., \& Yebes, R. B. Hemodynamic effects of isoxsuprine in cardiac failure. Chest, 86(5), 736-740. (1984).

[17] Nabirotchkin, S., Peluffo, A. E., Rinaudo, P., Yu, J., Hajj, R., \& Cohen, D. Next-generation drug repurposing using human genetics and network biology. Current opinion in pharmacology. https://doi.org/10.1016/j.coph.2019.12.004. (2020).

[18] Gysi, D. M., Valle, Í. D., Zitnik, M., Ameli, A., Gan, X., Varol, O., \& Barabási, A. L. Network medicine framework for identifying drug repurposing opportunities for COVID-19. arXiv preprint arXiv:2004.07229. (2020).

[19] Deftereos, S. N., Andronis, C., Friedla, E. J., Persidis, A., \& Persidis, A. Drug repurposing and adverse event prediction using high-throughput literature analysis: Drug repurposing and adverse event prediction. Wiley interdisciplinary reviews: Systems biology and medicine, 3(3), 323-334. (2011).

[20] Schooling, C. M., Huang, J. V., Zhao, J. V., Kwok, M. K., Au Yeung, S. L., \& Lin, S. L. Disconnect between genes associated with ischemic heart disease and targets of ischemic heart disease treatments. EBioMedicine, 28, 311315. (2018).

[21] Kim, S., Thiessen, P. A., Bolton, E. E., Chen, J., Fu, G., Gindulyte, A., Bryant, S. H. PubChem substance and compound databases. Nucleic acids research, 44(D1), D1202-D1213. (2016). 
[22] Banerjee, P., Eckert, A. O., Schrey, A. K., \& Preissner, R. ProTox-II: a webserver for the prediction of toxicity of chemicals. Nucleic acids research, 46(W1), W257-W263. (2018).

[23] Randhawa, M. A. Calculation of LD50 values from the method of Miller and Tainter, 1944. J Ayub med coll Abbottabad, 21(3), 184-185. (2009).

[24] Masoudi-Sobhanzadeh, Y., Omidi, Y., Amanlou, M., \&
Masoudi-Nejad, A. Drug databases and their contributions to drug repurposing. Genomics, 112(2), 1087-1095. https://doi.org/10.1016/j.ygeno.2019.06.021. (2020).

[25] Yuniwati, C., Ramli, N., Purwita, E., Yusnaini, Y. Nurdahliana, N., Miko, A., Liana, I., Andriani, A., \& Maharani, M. Molecular docking for active compounds of scurrula atropurpurea as anti-inflammatory candidate in endometriosis. Acta informatica medica, 26(4), 254. https://doi.org/10.5455/aim.2018.26.254-257. (2018). 